\title{
DRAWING THE SHORT STRAW: DISPROPORTIONAL EFFECTS OF RUSSIAN SANCTIONS ON CENTRAL EUROPE AND THE BALTIC STATES
}

\author{
Jacqueline Dufalla \\ Central European University
}

\begin{abstract}
In 2014, the agricultural sanctions Russia imposed on the European Union (EU) had a perceivable impact on the EU's economy. Yet the sanctions arguably had a disproportionate impact, which suggests they were particularly successful in exposing underlying issues within the EU. Specifically, former Soviet bloc countries and southern European countries were far more greatly impacted by the sanctions than the larger western EU member states. This brings to light problems of disproportionate representation of member states within decision-making processes (especially within the Committee for Agriculture and Rural Development), and the fragility of the EU's internal cohesion. By comparing typical decision-making processes of the EU with its responses during times of crisis, it becomes clear that the EU's decision-making process and its internal cohesion with regard to economic assistance for former Soviet states, are vulnerable to Russia's actions. The essay will conclude with recommendations on how to improve EU decisionmaking during times of crisis to counter this vulnerability.
\end{abstract}




\section{Introduction}

In March 2014, the United States (US), the European Union (EU), and other regions issued a series of sanctions against Russia due to the annexation of Crimea. The sanctions included freezing Russian assets abroad and restricting travel. Russia in turn imposed sanctions against the US and EU on agricultural products, specifically fruits, vegetables, dairy, and meat, in August 2014. Agricultural exports to Russia in 2013 were worth $€ 11$.8bn (BBC, "Russia hits West" 2014), and the sanctions particularly affected the fruits and vegetables sector. In this sector, the sanctions affected the EU disproportionately, and specifically affected former Soviet bloc countries, Poland and Lithuania. Additionally, sanctions harmed the stability of the already fluctuating Common Agriculture Policy (CAP) while bringing to light issues of internal cohesion.

Therefore, the situation highlights several challenges to multiple areas of EU policy. The sanctions against the EU consequently allow for a unique opportunity to make a comparison between the EU during its normal decision-making process and during times of crisis. This essay will first show how the 2013 CAP reforms were decided and implemented. It will then explore how and which actions were taken to counter the sanctions and their successes and limitations. The focus is on the representation in the European Parliament ${ }^{1}$ in particular, as, after the Lisbon Treaty in 2009, it was given more authority in the CAP. The sanctions were a reminder to the EU that Russia can have a significant impact on internal EU politics. The sanctions emphasized the disproportionate vulnerability of some EU member states to Russia and contributed to their disquiet. This essay will thus also explore what the EU has done to counter this feeling and proffer ideas to improve relations between EU member states.

\section{EU Agriculture Trade}

Since the collapse of the Soviet Union and the accession of the former Soviet bloc countries ${ }^{2}$ into the European Union, Russia and the EU have been strong agricultural trading partners. As of 2013, the EU has exported $10 \%$ of its agricultural goods to Russia, making Russia the EU's second largest agricultural market after the US (European Commission 2014a). Meanwhile, 19\% of Russia's agricultural exports went to the EU (BBC, "Russia hits West" 2014). Meanwhile, the EU was sensitive to changes in agriculture trade due to the predetermined 2013 CAP reforms, further exacerbated by Russian sanctions. In addition, the CAP had undergone decision-making procedure revisions, particularly from the Lisbon Treaty, which came into full effect in December 2009. However, as Greer and Hind (2012) assert, it is unlikely that these changes had anything but an incremental effect. Even with the European Parliament taking a larger role in CAP decision-making, they attest that, if anything, the Treaty's effect may reinforce the "status quo around the state-assisted paradigm..." (Greer \& Hind 2012, 339). In other words, the general procedure of large blanket aid programs to states has not changed.

This section will cover EU-Russia relations before the sanctions, focusing on the 2013 CAP reforms, and then will analyze the policy changes the EU has made in response to Russia's agricultural sanctions. This paper will compare how the EU functions with and without external pressure during its decision-making, as well as demonstrate the type of effect the Russian sanctions had.

\section{a. 2013 CAP Reforms}

Due in part to the 2004 EU expansion, the CAP required adjustment as many of the former Soviet bloc countries were agricultural producers, however their prices and standards were not quite at the EU level

\footnotetext{
${ }^{1}$ The European Parliament is considered the most representative EU institution, as its members are directly elected by the citizens. Many of its duties are shared equally with the European Council, but it also elects the Commission's president.

${ }^{2}$ In this paper, former Soviet bloc countries include Bulgaria, the Czech Republic, Estonia, Hungary, Latvia, Lithuania, Poland, Romania, and Slovakia.
} 
(Ciaian \& Swinnen 2007, 7). Before integration, approximately $4.3 \%$ of the EU-15 labor force worked in agriculture, forestry, hunting, and fishing, while about $21.5 \%$ of the population in the Central and Eastern European Countries (CEECs) worked within these sectors (Manzocchi 2003, 362). Clearly the CEECs needed special attention during the 2004 integration. The lack of domestic agricultural support within the CEECs led to the EU imposing a gradual increase in direct payments to CEEC agricultural producers over the first ten years of their membership to the EU (Ryan 2004, 4-5). This meant that by 2013, the EU should have lifted the restrictions on subsidies to the CEECs (ibid.). The CEECs gained access to the single market, farmers received higher prices for their products, and the countries now had access to direct payments and rural development grants (Ryan 2004, 4). The access to the single market also increased investment of capital in the region, which is a factor of production the CEECs have always lacked (Manzocchi 2003, 321). The CEECs additionally gained access to a larger international market, especially in Central Asia (Ciaian \& Swinnen 2007, 11). In short, joining the EU revitalized the agricultural sectors of the CEECs, which were especially in flux after the 1990s and the collapse of the Soviet system (Ciaian \& Swinnen 2007, 11). Due to early actions by the EU, the CEECs were more or less appropriately integrating into the CAP, and the EU would have almost ten years before needing to address the issue of subsidies again.

2013 was thus an important year for European agriculture, as it was the deadline for the EU to revise the CAP. Simultaneously, the EU had to manage agricultural sanctions imposed by Russia, which will be discussed in more detail later in this paper. In addition, the EU was still recovering from the 2008 economic crisis, which especially hurt southern EU countries, including strong agricultural producers such as Greece and Spain. However, it should be noted that in 2013, the EU was not technically in a crisis, despite still dealing with the aftermath of the 2008 economic crisis. The revision of the CAP was a previously scheduled reassessment and was not spurred on by external political pressure. The European Commission, as the executive and primary legislative body of the EU, largely led the proceedings. The actual decision-making process began three years earlier with an online public debate led by Dacian Cioloş, Commissioner for Agriculture and Rural Development, ${ }^{3}$ from April to June 2010. It focused on four main issues: the necessity of the CAP, citizen expectations, the need for reform, and the tools for the future CAP (European Commission 2015d). This stage seems to have incorporated one of the solutions to the EU's democratic deficit ${ }^{4}$ proffered by Lucia Vesnic-Alujevic and Rodrigo Castro Nacarino (2012). The EU, they argued, should include citizens in the decision-making process, specifically through the internet (ibid, 68). The EU effectively employed this strategy for the CAP to its credit.

The results were then discussed at a conference in July 2010. Experts, think-tank representatives, NGOs, representatives from the food chain process, and members of EU institutions attended the conference and participated in workshops (European Commission 2015b). Some panels focused on a specific sector, such as civil society, or an issue, like food security. There were several other conferences held in 2010, with many representatives from different sectors of society, similar to those who participated in the July conference. The Single CMO Management Committee and the Rural Development Evaluation Expert Committee $(\mathrm{ExCO})^{5}$ then met during 2011 and 2012 to hammer out issues and propose solutions to the CAP. In 2011, the Commission made proposals concerning monitoring and evaluating the CAP (European Commission 2015c). Two years later, in June 2013, the European Parliament, Commission, and Council finally agreed on the proposals. In December 2013, the proposals were accepted by the EU Council of Agriculture Ministers (European Commission 2015a).

\footnotetext{
${ }^{3}$ Agriculture and Rural Development is the sector of the European Commission responsible for the CAP.

4 "Democratic deficit" is a term often used with regard to the EU. Typically, it refers to feelings citizens have that EU institutions are not held accountable because of their complex structures. It also suggests that EU legislation is so complex that an ordinary citizen could not understand it, and is thus at the mercy of legislators.

${ }^{5}$ Both are committees found in the Agriculture and Rural Development sector of the European Commission.
} 
While the number of proposals and adjustments are numerous and extremely detailed, there are only a few on which this essay will focus. While EU institutions ${ }^{6}$ agreed to end sugar quotas by 2017 , other sectors received enhanced budgets, including the fruit scheme (Eteris 2013). The "fruit scheme," or the plan for the fruit sector, falls under the vegetables, fruits, and olives sub-group, one of five in the CAP (Molle 2006, 154). Most importantly, the EU decided to end historically-based direct payments. This means that countries that traditionally received more payments according to their length of time in the EU will have to gradually lower their intake. Those who received lower payments, primarily those who joined in 2004 and afterward, will slowly receive more payments. The idea was to promote external convergence of direct payments by 2019. Former Soviet bloc countries receive disproportionately low direct payments for all sectors. For example, in 2012, Lithuania received $€ 144 /$ hectare, Latvia $€ 97$, and Estonia $€ 117$, while Belgium received $€ 435$, the Netherlands $€ 457$, and Italy $€ 404$ (Kydra 2012). By 2019, Lithuania is expected to receive $€ 404 /$ hectare, which is just equal to Italy's 2012 amount (Kydra 2012). Thus, for the Baltic States, who traditionally received the lowest payments and staged a protest demanding more equal payments in 2012 (Kydra 2012), this was not necessarily good news. In 2011, Poland and the Baltic States were in agreement that the direct payments should be equal, rather than more equal, but when the idea of gradual convergence was introduced, Poland abandoned the Baltic States (Willis 2011).

Overall, the CAP reforms were not met with great enthusiasm, due to the fact that the main project, focusing on greening the CAP, was hailed as too broad and not environmentally focused enough (Spence 2013). However, they were praised for how well the European Parliament and the other two European institutions worked together (ibid.). In short, it is evident that the 2013 CAP reforms were made in the frequent style of the EU, meaning it took a great deal of time to achieve a broad series of reforms. At the end, very few states and officials were left satisfied. Shortly, this essay will compare this process with how the reforms on the CAP were made under the pressure from Russian sanctions.

\section{b. Pre-sanctions relationship with Russia}

Since the accession of a large portion of former Soviet bloc countries in 2004, the EU has had to re-evaluate its approach to Russian relations. After years of oppression, it comes as little surprise that many former communist countries do not regard Russia favourably. Poland and Estonia are traditionally the most vigilant toward any signs of Russian aggression. Additionally, Central and Eastern Europe are typically the most dependent on Russian natural gas exports, and they attempt to maintain relationships between both Russia and the EU. ${ }^{7}$ Therefore, former Soviet bloc countries are often in a difficult situation. Most of the population recalls the former oppression, but the economic realities make Russia a significant trading partner.

Since 2013, the EU has maintained a positive agricultural trade balance of $€ 10$.2bn with Russia, making it the EU's second largest agricultural export market after the US (European Commission 2014a). For five years, Russia consistently imported $10 \%$ of the EU's total agricultural exports (European Commission 2014a). Specifically, Russia imported mainly fruit, cheese, and pork. Russia also imported approximately $46 \%$ of the EU's total pear and apple exports (European Commission 2014a). Fruit accounts for 7\% of the total EU agricultural output, but the sector is more important for certain countries. For southern European countries, especially Greece, Cyprus, Malta, and Portugal, fruit exports make up a third of their total agricultural exports (European Commission 2014b). The main fruit exporters to Russia, however, are Poland, Lithuania, Belgium, and Spain, with Poland exporting $41 \%$ of its total fruits to Russia (European Commission 2014b). It is clear that before the sanctions, Russia was an important agricultural trading partner with the EU and with some member states in particular.

\footnotetext{
${ }^{6}$ Institutions here refer to the European Council, European Commission, and European Parliament.

${ }^{7}$ While, proportionally speaking, Germany and other Western European countries import the most from Russia, the former Soviet bloc countries are the most vulnerable. For instance, Poland, Estonia, Bulgaria, and Lithuania's natural gas supplies are nearly 100\% Russian gas (Chyong \& Tcherneva 2015).
} 


\section{c. Post-Sanctions: EU decision-making during the crisis}

Russia imposed sanctions against the EU, US and several other countries in August 2014. The EU was hit hardest among the partners, as its exports comprised $73 \%$ of the total ban (Juan 2014). The EU quickly took steps to counter this crisis. Fortunately, the 2014-2020 CAP reforms included new tools for crisis management that all of the EU institutions were able to use to legitimize their actions; this was also the first time such actions were necessary. Out of the EU institutions, the Commission took the first step, which set up a task force with weekly meetings to monitor the situation (ibid.). In early September, the European Council ${ }^{8}$ had a meeting specifically focused on the EU's response to the sanctions. They reported in their final press release:

Emergency market measures on fruit and vegetables and the milk sector have already been decided by the Commission. Most of the member states recognized the appropriateness of this support, while many called for the scope of the measures to be extended and the tools used to be diversified. (Council of the European Union 2014)

The Council agreed with the Commission, but required more support and more diversified tools. There was also an argument as to whether or not the agreed-upon agricultural budget ceiling should be raised due to this unprecedented crisis. There was not a resolution on this issue. A day earlier, on September 4, 2014, the Commission had a debate with the European Parliament's Committee on Agriculture and Rural Development about the best next steps to take. The Committee primarily acts on behalf of the Parliament in any agricultural or rural situations. It has the power to research best legislative options and work with the Council. The Committee and the Council both called for more money to be given to farmers and for that money to come from budgets outside of the agricultural budget (European Parliament 2014). Most significantly, there was little discussion about how to combat the fact that the sanctions hit some countries harder than others, specifically the Baltic States. Indeed, a Spanish member of the European Parliament, Clara Eugenia Aguilera García, complained that the Mediterranean crops were not receiving enough attention, and she continued by specifying "inter alia, citrus fruits, melons, water melons and tropical fruit, and calling for measures to be more balanced" (European Parliament: Committee on Agriculture and Rural Development 2014). This confirms Greer and Hind's suspicions that the changes to the CAP would not have a huge effect on CAP decision-making, as blanket state aid was provided.

This may be due to misrepresentation in the Parliament's Committee on Agriculture and Rural Development, which again verifies Greer and Hind's reservations. The Committee is heavily dominated by the larger member states. Of the 90 members in the Committee, only $17.6 \%$ of them come from former Soviet bloc countries (European Parliament; see Graph 1). As they represent nine out of the 28 member states, the percentage should be closer to $32 \%$ for proportional representation.

\footnotetext{
${ }^{8}$ The European Council is made up of the heads of all of the member states. It typically aids in providing the general direction for the $\mathrm{EU}$ and becomes more involved during times of crises.
} 
Additionally, many of the former bloc countries have high employment in agriculture, and a high portion of their total exports consist of agricultural goods (see Graph 2). The Baltic countries have a high number of people employed in agriculture, but Latvia, for instance, has only one representative on the Committee. Meanwhile, countries like the United Kingdom have

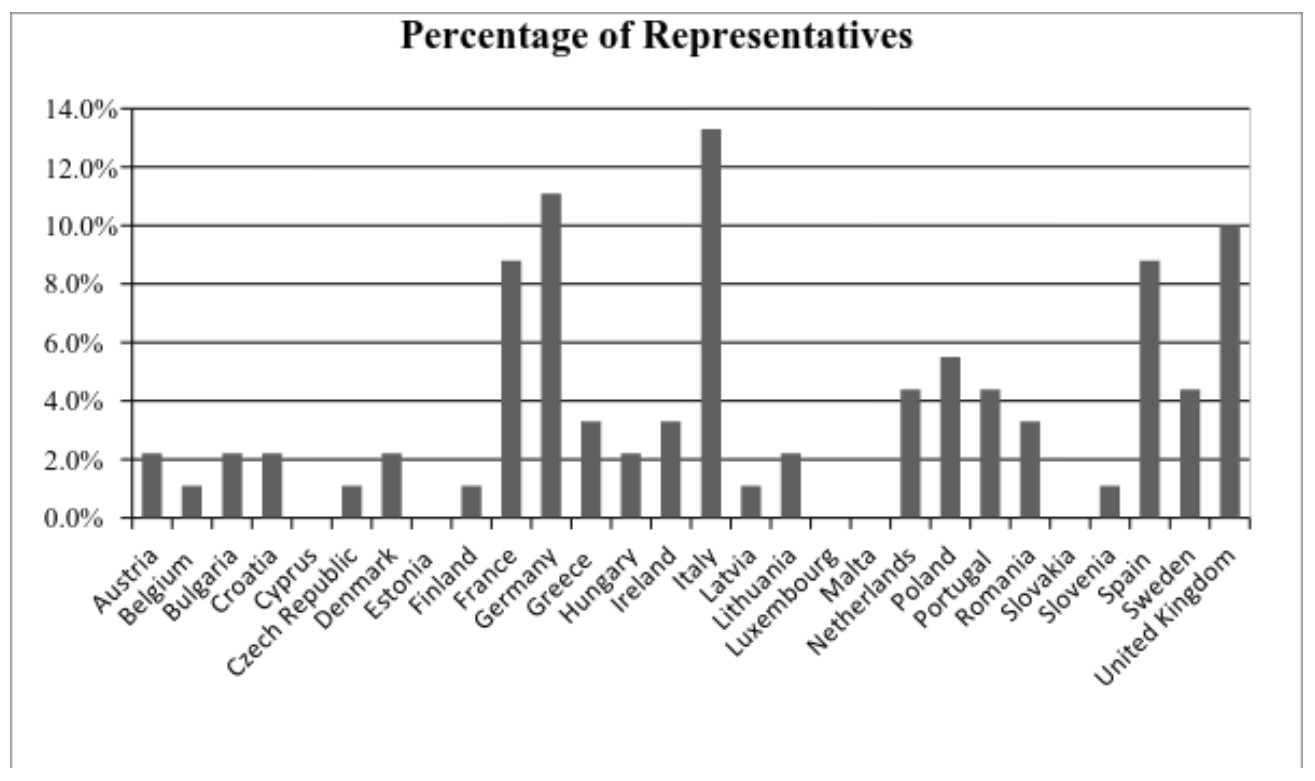

Graph 1. Percentage of Representatives in the European Parliament's Committee on Agriculture and Rural Development (Source: Author)

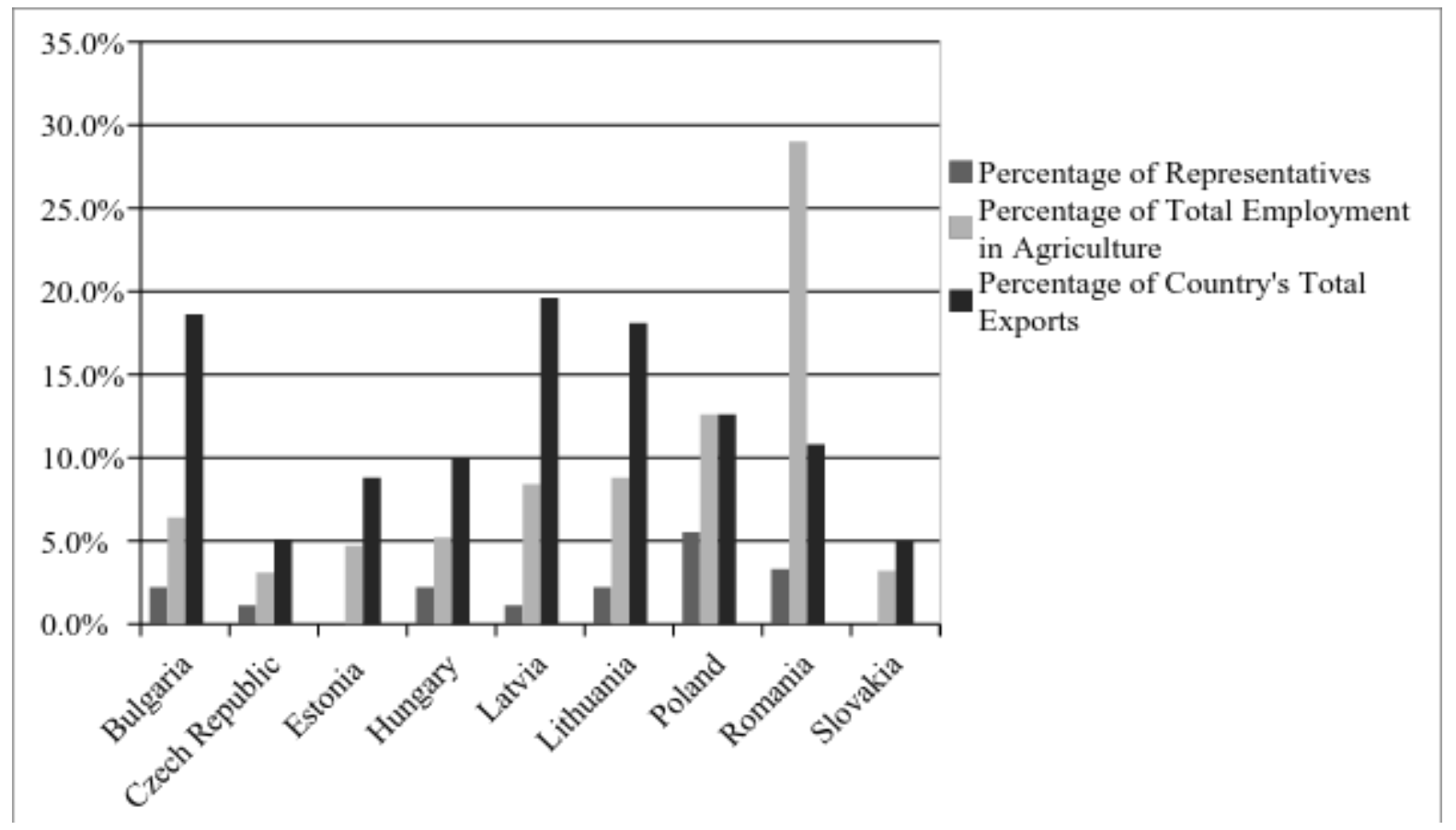

Graph 2. Former Soviet Bloc Countries representation in the Parliament's Committee on Agriculture and Rural Development versus agricultural statistics (Source: Author) 
$10 \%$ of the representatives, with an agriculture workforce of $1.2 \%$, and only $5.6 \%$ of total UK exports are agricultural goods (See Appendix 1 for full statistics and sources).

While some countries, like Germany, contribute a larger portion to the total agricultural exports of the EU, most of the larger EU countries do not heavily rely on agricultural exports. Chart 1 (see below) is a list of the ten countries in the EU that are most dependent on exporting agricultural goods. Despite having the highest number of representatives, Spain and France are only the eighth and ninth most reliant on agricultural exports, respectively. Meanwhile, four of the countries are former Soviet bloc countries and only have $12.2 \%$ of the representatives among them which is $5.5 \%$ less than France and Spain combined.

Chart 1. EU countries most dependent on agricultural exports

\begin{tabular}{|l|r|r|}
\hline Country & $\begin{array}{l}\text { Percentage of Country's } \\
\text { Total Exports }\end{array}$ & $\begin{array}{l}\text { Percentage of } \\
\text { Representatives }\end{array}$ \\
\hline 1. Latvia & $19.6 \%$ & $1.1 \%$ \\
\hline 2. Denmark & $19.0 \%$ & $2.2 \%$ \\
\hline 3. Bulgaria & $18.6 \%$ & $2.2 \%$ \\
\hline 4. Cyprus & $18.2 \%$ & $0.0 \%$ \\
\hline 5. Lithuania & $18.1 \%$ & $2.2 \%$ \\
\hline 6. Greece & $17.8 \%$ & $3.3 \%$ \\
\hline 7. Netherlands & $15.8 \%$ & $4.4 \%$ \\
\hline 8. Spain & $15.0 \%$ & $8.8 \%$ \\
\hline 9. France & $13.9 \%$ & \\
\hline 10. Poland & & \\
\hline
\end{tabular}

(Source: Author)

Thus, while some countries were hit harder than others by the sanctions, some Members of Parliament were calling for more balanced support to all farmers, rather than targeting the hardest-hit areas. In particular, this imbalance ignores the significance of the former bloc countries, including the CEECs and Baltic States. This appears to be due to the fact that the Parliament mainly relied on its Committee for Agriculture and 
Rural Development, which is dominated by countries that are not as economically reliant on agricultural exports.

The Commission ultimately introduced three overarching policies within a month of the Russian sanctions, and after altering and debating them in Parliament, they were eventually passed (Juan 2014). The first was concerned with market measures and harvesting. After briefly suspending emergency measures in midSeptember, by late September, the EU introduced an extra $€ 165$ million temporarily into the agricultural budget in order to protect the fruit sector specifically (ibid.). ${ }^{9}$ Secondly, the Commission introduced temporary private storage for dairy products, and this quickly closed at the end of September (ibid.). The final resolution passed was the policy promotion of European agricultural products. That portion of the CAP budget received an additional $€ 60$ million (ibid.). The Commission was quick to introduce procedures to aid those affected by the sanctions, and the Parliament and Council did not delay passing these propositions. However, the EU did not take into account the disproportionate effect that the sanctions had on the CEECs and Baltic States. As a result, support to the EU agricultural producers was generalized.

\section{d. Successes and limitations of EU decision-making}

Comparing EU policy implementation based on these circumstances is a beneficial way of uncovering effective methods and problem areas within EU decision-making. First, it must be said that the EU has made great strides in including the most representative institution, the European Parliament, in the decisionmaking process. In both the pre- and post-sanction decision-making processes, Parliament had a much greater say than it typically does with the CAP — which is technically under Commission supervisiondespite the fact that Parliament controls the budget. Even when sanction timing was critical, Parliament still contributed. That being said, during the crisis Parliament was primarily represented by the Committee on Agriculture and Rural Development, which is heavily dominated by the larger member states and, as previously mentioned, is not representative of the agricultural realities of member states.

When the crisis hit, the EU failed to take differences into consideration, and its institutions were not representative of the hardest hit countries. This is a serious flaw in the EU's crisis management decisionmaking process. If the EU ignores the struggles of certain member states, already vulnerable countries may be left in a more precarious position. As previously mentioned, these countries in particular must delicately balance their actions between the EU and Russia, and accordingly, their responses were not as bold as those in Western Europe. In recent years the EU has begun to worry about Hungarian president Viktor Orbán's gas dealings with Russian president Vladimir Putin and his generally positive relationship with Russia (Halasz 2015). Similarly, the president of the Czech Republic, Milos Zeman, had planned to attend Russia's annual Victory Day celebration in 2015, but after intense pressure from the EU and the US, he visited the country but skipped the parade (Virostkova 2015). Slovak Prime Minister Robert Fico acted similarly (Grove 2015). While the Baltic States and Poland are very outspoken about Russia's aggression, other CEECs seem to be more wary of being so direct, exposing the vulnerability of the EU's internal cohesion. At the same time, the Baltic States wish the EU was doing more to chastise Russia. They are particularly nervous after the annexation of Crimea and with the current crisis in Ukraine, as they, too, have large Russian diasporas (Adler 2015). Therefore, during times of crisis, especially a crisis involving Russia, the EU's internal cohesion is tested, and ultimately, the EU must reassure the former Soviet bloc states. In the future, this will be an important consideration for the EU, and perhaps require an additional task force consisting of the most affected countries in that specific crisis.

There also appears to be an issue of widening versus deepening; because there are so many countries now in the European Union, the EU cannot deeply explore specific problems during times of crisis. Based on the comparison between the two decision-making processes, it seems as though Kelemen et al. (2014) are

\footnotetext{
${ }^{9}$ It is important to note that this was a blanket support system, i.e., countries affected the hardest were not duly compensated (European Commission 2014d).
} 
correct when they assert that widening may hurt in the short term, but may strengthen long-term benefits, such as being able to make significant institutional changes (ibid., 647). The authors also stated that the success of deepening depends not on the number of member states, but on their attitudes, i.e., whether they prefer to maintain the status quo or are more cooperative (ibid., 651). In this case, when it was a long-term plan (e.g., CAP 2020), there was more discussion with member states that are typically more cooperative, i.e., former bloc countries, who still have less of a say, but are increasingly included in the discussion. Over the long term, the EU institutions were able to come to a decision about the CAP with actors who typically have not been able to participate as much, specifically the European Parliament and EU citizens. Even though the outcome left the Baltic States dissatisfied, they still gained an increase in agricultural support. It was also acknowledged that the EU member states had different agricultural needs, and should be treated accordingly.

Meanwhile, when it was a short-term issue, the EU institutions, primarily the Commission and Parliament, which depended on specific committees, could not deeply explore a problem while also dealing with the many members. This is because during the crisis, the bigger member states who typically prefer maintaining the status quo took charge, and there was very little involvement from the smaller member states. Thus, the ultimate solution was a blanket aid program, rather than more targeted actions. From this perspective, it would be beneficial to have a mix of large and small countries in crisis management to ensure a comprehensive and inclusive solution. This could be a committee composed of the most affected and vulnerable countries. It is unwise for the EU to rely on countries who maintain the status quo during times of crisis because such times require a different and cooperative approach.

\section{Conclusion}

Based on the two case studies of EU decision-making regarding the CAP, there are several interesting patterns that emerge. First, the EU has improved the management of its democratic deficit and has even begun to utilize internet forums. The EU has also been successful in deepening the CAP, notable in the CAP 2020 reforms, due to its inclusion of most member states although the most vulnerable countries still had less of a say due to their size. This dynamic changes, however, during a crisis, such as the sanctions Russia imposed on the EU. In this example, the EU relied more heavily on larger member states, which meant the smaller member states, who were coincidentally more affected by the sanctions, were ignored. This issue primarily occurred due to the skewed over-representation of larger countries on the main committee, who traditionally favour the status quo. While a large portion of the former Soviet bloc countries have greater numbers employed in the agriculture sector and are more economically dependent, they still have a lower proportion of representatives on the Committee for Agriculture and Rural Development.

This Committee, which primarily handled the Russian sanctions, was left to work rather independently of its governing body, the European Parliament. Since the Committee did not contain a representative member from each country, or even a majority from those hurt most by the sanctions, its actions arguably did not accurately respond to the reality of the problems caused by the Russian sanctions. Had there been greater involvement from the European parliamentarians, or had they created a more balanced committee, it is likely the response would have been more appropriate. While the Committee did favour the countries that were the largest agricultural producers, such as France, Italy, and Germany, it failed to recognize that these larger countries were not as dependent on agricultural trade for their economies, and they were thus not as vulnerable to the Russian sanctions. Instead, the former communist countries dealt with both stronger effects from the sanctions and less representation on the Committee. 
This is a dangerous problem for the EU, and it should not be taken lightly. The sanctions brought to light issues concerning internal cohesion and the disproportionate vulnerability faced by the former Soviet bloc - the CEECs and the Baltic States. In the future, the EU should source solutions and aid requirements from countries most greatly affected by crises. The EU must reassure former Soviet bloc countries of its support so they do not feel exposed or abandoned to perceived Russian aggression. This could be rectified by establishing a committee composed only of the most affected member states. It is therefore important for the EU to address these limitations before they become serious issues in long-term or crisis decision-making.

\section{REFERENCES}

Adler, Katya. 2014. "Baltic Nations "Nervous about Russian Threat"”. BBC. March 7. http://www.bbc.com/news/world-europe-31775358

BBC. 2014. "Russia hits West with food import ban in sanctions row." August 7. http://www.bbc.com/news/world-europe-28687172

Chyong, Chi-Kong and Vessela Tcherneva. 2015. "Europe's Vulnerability on Russian Gas." European Council on Foreign Relations. March 17. http://www.ecfr.eu/article/commentary_europes_vulnerability_on_russian_gas

Ciaian, Pavel and Johan F.M. Swinnen. 2007. "Distortions to Agricultural Incentives in Central and Eastern Europe.” August 7. http://core.ac.uk/download/files/153/6457633.pdf

Council of the European Union. 2014. "Press Release: Extraordinary Council Meeting: Agriculture and $\quad$ Fisheries." September 5. http://www.consilium.europa.eu/uedocs/cms_Data/docs/pressdata/en/agricult/144667.pdf

Eteris, Eugene. 2013. "New Union's CAP Reform for Baltic Farmers." The Baltic Course. October 28. http://www.baltic-course.com/eng/markets_and_companies/?doc=82678

European Commission. 2014a. "Agricultural trade in 2013: EU gains in commodity exports" http://ec.europa.eu/agriculture/trade-analysis/map/2014-1_en.pdf

- 2014b. "Analysis of the EU fruit and vegetables sector" September 26. http://ec.europa.eu/agriculture/russian-import-ban/pdf/fv-production_en.pdf

- 2014c. "EU agriculture - Statistical and economic information -2013." http://ec.europa.eu/agriculture/statistics/agricultural/2013/pdf/b0-1-2_en.pdf

- 2014d. "Regulations" Official Journal of the European Union. August 21. http://eurlex.europa.eu/legal-content/EN/TXT/PDF/?uri=CELEX:32014R0913\&from=en 
-. From last date modified 30 January 2015a. "The Common Agriculture Policy after 2013." http://ec.europa.eu/agriculture/cap-post-2013/

-. From last date modified 30 January 2015b. "'The CAP post-2013' Conference on the public debate, Brussels, July 19-20, 2010.” http://ec.europa.eu/agriculture/cap-post2013/conference/19-07-2010_en.htm

—. From last date modified 30 January 2015c "Monitoring and evaluation for the CAP post-2013.". http://ec.europa.eu/agriculture/cap-post-2013/monitoring-evaluation/index_en.htm

—. From last date modified 30 January 2015d. "Public Debate on the CAP post-2013." http://ec.europa.eu/agriculture/cap-post-2013/debate/index_en.htm

European Parliament. 2014. "MEPs welcome signs of change in Ukraine and urge EU to stand up to Russia." September 18 . http://www.europarl.europa.eu/news/en/newsroom/content/20140918IPR65201/html/MEPs-welcome-signs-of-hope-in-Ukraine-andurge-the-EU-to-stand-up-to-Russia

European Parliament. N.d. "European Parliament Committees: Agriculture and Rural Development: Members" http://www.europarl.europa.eu/committees/en/agri/members.html;jsessionid=4F7509E60F 436ED2B265678FB8B1D767.node1 ?action=8

European Parliament: Committee on Agriculture and Rural Development. 2014. "Russian Ban: Agriculture Committee calls for more actions and money to support EU farmers." September 5.

http://www.europarl.europa.eu/pdfs/news/expert/infopress/20140905IPR59401/20140905I PR59401_en.pdf

Greer, Alan and Thomas Hind. 2012. "Inter-institutional decision-making: The case of the Common Agricultural Policy." Policy and Society. 31: 331-341.

Grove, Thomas. 2015. "Putin Puts on Vast Victory Day Parade in Moscow." The Wall Street Journal. May 9. http://www.wsj.com/articles/putin-puts-on-vast-victory-day-parade1431167707.

Halasz, Adam. 2015. “Orban gives Putin warm welcome.” EUObserver. February 18. https://euobserver.com/beyond-brussels/127693

Juan, Ana Martinez. 2014. "Russian measures against European Union agricultural products." European Parlimentary Research Service. October 3. http://epthinktank.eu/2014/10/03/russian-measures-against-european-union-agriculturalproducts/

Kelemen, R. Daniel, Anand Menon and Jonathan Slapin. 2014. "Wider and deeper? Enlargement and integration in the European Union." Journal of European Public Policy. 21 (5): 647-663. 
Kydra, Marek. 2012. "Baltic countries demand fairer redistribution of CAP payments." Agriculture and Rural Conventions. July 2. http://www.arc2020.eu/front/2012/07/balticcountries-demand-fairer-redistribution-of-cap-payments/

Manzocchi, Stefano. 2003. The Economics of Enlargement. Palgrave: New York.

Molle, Wilhelm. 2006. The Economics of European Integration: Theory, Practice, Policy. Aldershot, England: Ashgate.

Ryan, Michael. 2005. "Enlargement Costs of the Common Agricultural Policy." Bachelor's diss., University of Stanford. http://economics.stanford.edu/files/Theses/Theses_2005/Ryan.pdf

Spence, Timothy. 2013. "CAP 2014-2020: A long road to reform." EurActiv. July 4. http://www.euractiv.com/general/cap-reform-post-2013-linksdossier-508393

Vesnic-Alujevic, Lucia and Rodrigo Castero Nacarino. 2012. "The EU and its democratic deficit: problems and (possible) solutions." European View, (June): 63-70.

Virostkova, Lucia. 2015. "Czech and Slovak Leaders Divided over Russia's 9 May Parade." EUObserver, April 13. https://euobserver.com/beyond-brussels/128291

Willis, Andrew. 2011. "EU states oppose plans to end farm 'subsidy millionaires'." EUObserver, March 18, https://euobserver.com/news/32014. 


\section{Appendix 1}

\begin{tabular}{|c|c|c|c|c|}
\hline Country & $\begin{array}{l}\text { Percentage of } \\
\text { Representatives }^{10}\end{array}$ & $\begin{array}{l}\text { Percentage of Total } \\
\text { Employment in } \\
\text { Agriculture }^{11}\end{array}$ & $\begin{array}{l}\text { Percentage of } \\
\text { Country's Total } \\
\text { Exports }^{12}\end{array}$ & $\begin{array}{l}\text { Total Agricultural } \\
\text { Exports } \\
\text { (Billions of Euros) }^{13}\end{array}$ \\
\hline Austria & $2.2 \%$ & $4.9 \%$ & $7.8 \%$ & 10.3 \\
\hline Belgium & $1.1 \%$ & $1.2 \%$ & $9.7 \%$ & 34.2 \\
\hline Bulgaria & $2.2 \%$ & $6.4 \%$ & $18.6 \%$ & 4.1 \\
\hline Croatia & $2.2 \%$ & $13.7 \%$ & $11.3 \%$ & 1.1 \\
\hline Cyprus & $0.0 \%$ & $2.9 \%$ & $18.2 \%$ & 0.3 \\
\hline $\begin{array}{l}\text { Czech } \\
\text { Republic }\end{array}$ & $1.1 \%$ & $3.1 \%$ & $5.1 \%$ & 6.2 \\
\hline Denmark & $2.2 \%$ & $2.6 \%$ & $19.0 \%$ & 15.8 \\
\hline Estonia & $0.0 \%$ & $4.7 \%$ & $8.8 \%$ & 1.1 \\
\hline Finland & $1.1 \%$ & $4.1 \%$ & $4.6 \%$ & 2.6 \\
\hline France & $8.8 \%$ & $2.9 \%$ & $13.9 \%$ & 60.8 \\
\hline Germany & $11.1 \%$ & $1.5 \%$ & $6.2 \%$ & 68 \\
\hline Greece & $3.3 \%$ & $13.0 \%$ & $17.8 \%$ & 4.9 \\
\hline Hungary & $2.2 \%$ & $5.2 \%$ & $10.0 \%$ & 8.1 \\
\hline Ireland & $3.3 \%$ & $4.7 \%$ & $11.9 \%$ & 10.3 \\
\hline Italy & $13.3 \%$ & $3.7 \%$ & $8.6 \%$ & 33.6 \\
\hline Latvia & $1.1 \%$ & $8.4 \%$ & $19.6 \%$ & 2.1 \\
\hline
\end{tabular}

\footnotetext{
${ }^{10}$ From the European Parliament: D767.node1?action $=8$

${ }^{11}$ From European Commission, Agriculture and Rural Development: http://ec.europa.eu/agriculture/statistics/agricultural/2013/pdf/c5-1-351_en.pdf

${ }^{12}$ From European Commission, Agriculture and Rural Development: http://ec.europa.eu/agriculture/statistics/factsheets/index_en.htm

${ }^{13}$ From European Commission, Agriculture and Rural Development: http://ec.europa.eu/agriculture/statistics/factsheets/index_en.htm
} http://www.europarl.europa.eu/committees/en/agri/members.html;jsessionid=4F7509E60F436ED2B265678FB8B1 
14 Review of European and Russian Affairs 10 (1), 2016

\begin{tabular}{|l|l|l|l|l|}
\hline Lithuania & $2.2 \%$ & $8.8 \%$ & $18.1 \%$ & 4.4 \\
\hline Luxembourg & $0.0 \%$ & $1.3 \%$ & $7.2 \%$ & 1 \\
\hline Malta & $0.0 \%$ & $1.0 \%$ & $4.5 \%$ & 0.1 \\
\hline Netherlands & $4.4 \%$ & N/A & $15.8 \%$ & 17.7 \\
\hline Poland & $5.5 \%$ & $12.6 \%$ & $12.6 \%$ & 19.4 \\
\hline Portugal & $4.4 \%$ & $10.5 \%$ & $10.2 \%$ & 4.8 \\
\hline Romania & $3.3 \%$ & $29.0 \%$ & $10.8 \%$ & 5.3 \\
\hline Slovakia & $0.0 \%$ & $3.2 \%$ & $5.0 \%$ & 3.3 \\
\hline Slovenia & $1.1 \%$ & $8.3 \%$ & $5.9 \%$ & 1.5 \\
\hline Spain & $8.8 \%$ & $4.4 \%$ & $15.0 \%$ & 35.9 \\
\hline Sweden & $4.4 \%$ & $2.0 \%$ & $4.0 \%$ & 5.1 \\
\hline $\begin{array}{l}\text { United } \\
\text { Kingdom }\end{array}$ & $10.0 \%$ & $1.2 \%$ & $5.6 \%$ & 22.6 \\
\hline
\end{tabular}

(Source: Author) 
Published by the Centre for European Studies at Carleton University, Ottawa, Canada Available online at: journals.carleton.ca/rera/index.php/rera

RERA is an electronic academic peer-reviewed journal that publishes graduate, post-graduate, and young scholarly works. Topics relate to the European Union, it's Member States, the former Soviet Union, and Central and Eastern Europe. The journal is a joint project supported by the CanadaEurope Transatlantic Dialogue - a cross-Canada research network supported by the Social Sciences and Humanities Research Council of Canada (SSHRC) — along with the Institute of European, Russian and Eurasian Studies (Carleton University) and its associated research unit, the Centre for European Studies.

RERA aims to provide an accessible forum for research, to promote high standards of research and scholarship, and to foster communication among young scholars.

\section{Contact:}

Carleton University

The Centre for European Studies

1103 Dunton Tower

1125 Colonel By Drive

Ottawa, ON K1S 5B6

Canada

Tel: +01 613 520-2600 ext. 3117; E-mail: rera-journal@ carleton.ca

\section{Creative Commons License}

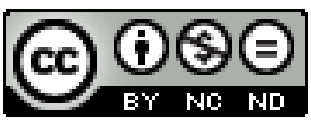

creativecommons.org/licenses/by-nc-nd/3.0

This Working Paper is licensed under a Creative Commons Attribution-Non-CommercialNo Derivs 3.0 Unported License (CC BY-NC-ND 3.0).

Articles appearing in this publication may be freely quoted and reproduced, provided the source is acknowledged. No use of this publication may be made for resale or other commercial purposes.

ISSN: 1718-4835

(C) 2016 The Author(s) 